\title{
Organization Performance Improvement using TQM
}

\author{
Ahlam Mohammed Alamri, Alaa Moued Alharthi, Dina Khaled Alharthi, Walaa Saleh \\ Alhabashi, Syed Hamid Hasan \\ Department of Information Systems \\ Faculty of Computing and Information Technology, \\ Department of Information Systems \\ King Abdulaziz University, Kingdom of Saudi Arabia
}

\begin{abstract}
The purpose of this research is to study the relation between the six Total Quality Management practices and the operational performance in one of the largest Saudi telecommunication company. The research shows how to improve organization performance using Total Quality Management. The data used in the research were collected through a survey that distributed in 421 employees in the company. By using Microsoft Office Excel the Cronbach's coefficient alpha value used to determine the reliability of the measurement and the correlation analysis used to find out the strength of the relation between six Total Quality Management practices and operational performance. The results of analyzing data are the result of the research. The research contains a literature review about different research that studies the effect of TQM in operational performance in different countries. The research contains also strategies and theories of TQM, and the final part is about research methodology (analyses and calculation).
\end{abstract}

\section{General Terms}

Total Quality Management

\section{Keywords}

Total Quality Management, Organizational Performance, TQM practice, Saudi Arabia, Telecommunication

\section{INTRODUCTION}

In the global marketplace levels of competition are increasing, so this resulted in quality becoming important to organizations and later Total Quality Management has become a key management issue. The meaning of word quality has changed because of the evolution of the world. Many authors defined quality in different aspects. Phil Crosby said quality is conformance to specifications. On the other hand, Joseph Juran said quality is fitness for use. The ISO 8402 defines the quality as the totality of features and characteristics of a product or services that bear on its ability to meet stated or implied needs[7]. Total Quality Management (TQM) is the optimization and integration of all the functions and processes of a business in order to make the customer satisfied and to achieve this goal the organizational processes should be continuously improved and this will lead to high quality in products and services. The main objectives of Total Quality Management are to improve the process, to prevent the defects, to measure system capacity, and to observe behavior changes over a period of time.

\section{LITERATURE REVIEW}

In the last years, a lot of researches were conducted all over the world on the topic of TQM, how organizations should implement it and the correlation between TQM and organization performance. This literature review will focus on researches that study the effect of TQM in organization performance in different countries.

In Pakistan, a few numbers of researchers studied the relationship between TQM and organization performance, there is a study focused on measuring the effect of TQM independent variables (supplier relationship, degree of customer focus, degree of employee involvement, benchmarking, work environment) on Small to Medium Enterprises (SMEs) non-financial performance in Gujranwala, Gujrat and Sialkot. Data were collected through a questionnaire with Likert scale (strongly agree, agree, neither agree nor disagree, disagree, strongly disagree). The result shows a strong correlation between an independent variable, which is TQM practices and dependent variable, which is SME non-financial performance.

In Jordan, researchers become more interested in TQM topics and some researchers studied the correlation between TQM practices and organizational performance in different sectors. Ali Bakhit Jaafreh from Shaqra University worked on research that investigates this relationship in banking sector in Jordan, he proposed a conceptual model that shows the correlation between TQM practices and organizational performance then a questionnaire was made and distributed to employees in 22 banks data collected. After analyzing, questionnaire results strongly support Jaafreh's conceptual model.

On the other hand, related industries of information have been significantly developed in Taiwan, which effects on the global economy. There is one research conducted to measure the effect of TQM on organizational performance in Taiwan. The study focuses on the correlation between TQM practices and companies' performance, TQM practices are: process management, management, leadership, design management, suppliers' management, customer focus, reporting and quality data, human resource. The study hypothesizes that TQM practice's effect positively on organizational performance and divided quality management, motivation into: to increase product quality, to improve employees moral, to improve firm's position in a market, to increase organization profits, to follow market trends, to reduce competitors' pressure, and to expand organization market share. To test the validity of this hypothesis a survey was conducted and distributed in 2005 to SME from Information Service Industry in Taiwan, the result shows that most strong quality management, motivation in organization are increasing product quality and improving firm's position in market, results also support the researcher's hypothesis that TQM practice's effect on organizational performance which increase customer satisfaction.

In Saudi Arabia, a lot of researches have been conducted in the domain of TQM; however, there were a few researches that focused on the TQM impact on organizational performance. Abdulrahman Alsughayir from Al Imam 
Muhammad bin Saud Islamic University studied the relationship between TQM and employee job satisfaction in particular, researcher focus on private firm in Saudi Arabia as a sample for his study, then a survey was distributed in 2013 to 350 employees in a large Saudi Telecom company with a $74.5 \%$ response rate.

The result shows that TQM has a strong impact on employee satisfaction which increases work quality and individual productivity.

\section{THE TOTAL QUALITY}

\section{MANAGEMENT (TQM) STRATEGY}

To be adopted any organization would be applied the quality approach, it should be understood strategic total management as a proactive situation rather than as just technique, or highlevel guarantee products and services. The strategic total quality adoption as one of organization part are supposed continuous evaluating management concept and administration practices by adopting innovation strategies, also it is important to develop organizational strategic culture.

The following strategies help organizations to develop the TQM process:

1. TQM Element Approach

2. Guru Approach

3. Organization Model Approach

4. Japanese Total Quality Approach

5. Award Criteria Approach

Below there are a brief about each strategy and its explanation.

\subsection{1st strategy: TQM Element Approach}

Early in 1980s the companies used his method, they learn and try to implement little parts of TQM. The TQM element approach takes all main business operations and organizational units to use the tools of TQM to make better improvements. Quality function deployment, quality circles, and statistical process control are examples of this approach[12].

\subsection{2nd strategy: Guru Approach}

This approach used technique on one of the leading quality thinkers as guide against which determines where the organization has weakness and make appropriate changing to fix that weakness.

\subsection{3rd strategy: Organization Model Approach}

By using this method the Malcolm Baldrige National received the Quality Award late of $80 \mathrm{~s}$, in this approach, there is individuals or team who visits the organization and takes the leadership role in TQM and determine their business process and reason of success then integrate these ideas with their own ideas to improve current organizational model adapted for their required specific organization.

\subsection{4th strategy: Japanese Total Quality Approach}

Florida Power and Light used this approach to implement TQM and to compete for and win the Deming Prize. By using Japanese total quality, organization would examine the technique of detailed implements and the strategy that used by
Deming Prize winning and use this experience to develop long range main plan for in-house use.

\subsection{5th strategy: Award Criteria Approach}

This approach, focus on the criteria of any quality awards for organization like, European Quality Award and, Deming Prize, to identify improvement areas. So the TQM implementation will focus on meeting specific award criteria. Despite, there are some people argue that this is not an appropriate use of award criteria, there are some organizations apply this approach and success to improvements.

\section{THEORY OF TOTAL QUALITY MANAGEMENT}

The techniques and tools of TQM based on theories to manage the process that concentrate on quality. Many experts have helped to formalize different viewpoints in quality management. From the most popular theories:

1. Deming Theory.

2. Joseph Juran Theory.

3. Crosby Theory.

Theory of total quality management can be summarized as follows[9]:

Table1: Summery of TQM Theories

\begin{tabular}{|c|c|}
\hline $\begin{array}{l}\text { Theory } \\
\text { Name }\end{array}$ & Theory Principles \\
\hline Deming & $\begin{array}{l}\text { 1. System of profound knowledge: } \\
\text { - System Knowledge: understanding } \\
\text { of the organization's processes and } \\
\text { systems, and how they work to } \\
\text { achieve the organization aim. } \\
\text { - Variation Knowledge: } \\
\text { understanding of the causes of } \\
\text { alteration. } \\
\text { Knowledge, Theory: } \\
\text { understanding the knowledge that } \\
\text { can benefit the organization. } \\
\text { Psychology Knowledge: } \\
\text { understanding peoples' attitudes, } \\
\text { and how they interact and work. } \\
\text { 2. Deming's 14 points of total quality } \\
\text { management[13]. } \\
\text { 3. The Plan-Do-Check-Act (PDCA) } \\
\text { cycle[13]. }\end{array}$ \\
\hline Juran & $\begin{array}{l}\text { Quality trilogy is (Joseph M. Juran; A. } \\
\text { Blanton Godfrey,1999): } \\
\text { 1. Quality Planning: understanding } \\
\text { customer needs and developing } \\
\text { products that met their needs. } \\
\text { 2. Quality Control: measuring and } \\
\text { evaluating performance. } \\
\text { 3. Quality Improvement: achieving } \\
\text { quality by focusing on long term goals. }\end{array}$ \\
\hline Crosby & $\begin{array}{l}\text { 1. Define quality as a compatibility to } \\
\text { requirements. } \\
\text { 2. Produce quality by prevention. }\end{array}$ \\
\hline
\end{tabular}




\begin{tabular}{|l|ll|}
\hline & $\begin{array}{l}\text { The performance standard of quality } \\
\text { is Zero Defects. }\end{array}$ \\
4. & $\begin{array}{l}\text { Measuring the quality by the price of } \\
\text { nonconformance. }\end{array}$
\end{tabular}

\section{TOTAL QUALITY MANAGEMENT AND ORGANIZATIONAL PERFORMANCE}

Since TQM is an important factor in organizations development in terms of decreasing product price, increasing profits, increasing product quality, minimizing production costs, gain competitive advantage over other organizations and increasing employees and managers' satisfactions, researchers in Saudi Arabia become more interested in TQM issues and studies, also some organizations have already started implementing TQM in its departments. One of important studies in TQM topic investigates the correlation between TQM and organizational performance, which this paper will focus on:

\subsection{Framework Model}

In order to study the relation between the operational performance and the TQM practices within the telecommunication company, a theoretical TQM model were developed to focus how this relation correlated and the direction between the pairs. The figure below shows the six TQM practice in the top and operational performance in the bottom and the relation between them:

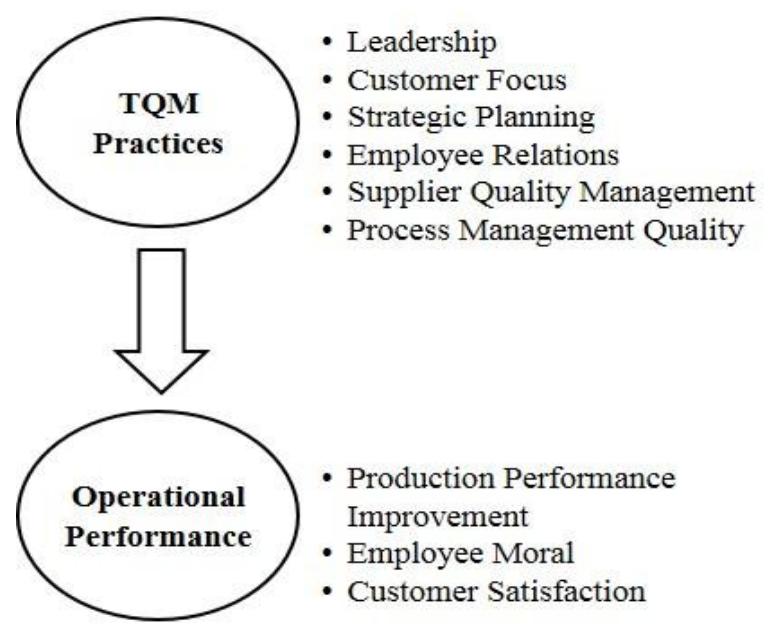

Figure 1: Framework Model

\subsection{Research Methodology}

The study is a correlation (on field) study implemented on one of the largest Telecommunication Company in Saudi Arabia during the period of 21st September 2014 till 2 November 2014 , and the company applies a quality management strategy that uses management practices as an input and company performance as an output. To find out how much TQM effect on organizational performance specific operational performance of the company, a questionnaire was conducted that contain seven parts related to each quality management practice and operational performance:

- $\quad$ Part 1 questions about Leadership

- Part 2 questions about Customer focus

- Part 3 questions about Strategic planning
- Part 4 questions about Employee relations

- Part 5 questions about Supplier quality management

- Part 6 questions about Process management quality

- Part 7 questions focus on company operational performance

Questionnaire distributed to a sample of 421 employees in the Saudi Telecommunication Company, using a Likert scale for answers to score from 1 to 5 , where 1 means strongly disagree, 2 means disagree, 3 means neither agree nor disagree, 4 means agree and 5 means strongly agree. The discussion about each factor of sex practices in the company as follows:

\subsubsection{Leadership}

Leadership is an important goal for any organization, and the telecommunication company targeted in this study is a leader in different fields. It's a leader company on employees' satisfaction by using a yammer social network, which is a free space for internal communications between employees, managers and decision makers in the company, this space allows them to share their feelings, concerns, problems and suggestions. The company also motivates their employees to participate in competitions with others to share their innovative ideas related to technology, telecommunication and advertising, then a voting campaign takes place and the most innovated idea gets a financing from the company to support it. On the other hand, the company plans to be led by transforming completely from telecommunication provider to information communication technology service provider (ICT) in 2020, by establishing data centers cross Saudi Arabia.

\subsubsection{Customer Focus}

International Organization for Standardization ISO 900014000 [15] emphasized that in order for the organizations to be customer focus, they are supposed to focus on their customers by understanding the requirements of their current and future customer, and should meet customer needs and strive to exceed customer expectations. Focusing on the customer is one of the important objectives of quality[7]. Customers are the most important factor and are a major key in the telecommunication company that targeted in this study by providing them with different services to serve and cover a big range of customers.

\subsubsection{Strategic Planning}

Strategic planning is a process of accomplishing the established vision, mission and goals of the organization. As illustrated by Juran that the strategic quality planning is developing a procedure to achieve the organization longterm goals by determining customer needs and respond to them by delivering the desired products or services[8]. In this study, the telecommunication company has clearly determined its vision, mission, objectives and values. It well defined longterm plan and a clear strategy to achieve growth and move from mobile telecom provider to a global player in ICT.

\subsubsection{Supplier Quality Management}

The organization's ability to satisfy the interests of different suppliers is a key factor of the success of TQM. Supply chain management in TQM "implies reducing and streamlining the supplier base to facilitate managing supplier relationships, developing strategic alliances with suppliers, working with suppliers to ensure that expectations are met, and involving suppliers early in the product development process to take 
advantage of their capabilities and expertise"[11]. Because the quality of input is directly related to the final product, the relationship between the organization and the supplier is important.

\subsubsection{Employee Relations}

"The concept of Total Quality Management emphasizes continuous improvement and this requires participation of every individual in the company"[6]. Employee relations are important factors making TQM job successful. The way to encourage employees and making them responsible for quality decisions and improvements is sharing information across functional groups of the organization[14]. If the relationships between employees are good and strong this will lead to positive results on organizations. The telecommunication company in this study often has a shorter decision making process, enabling a faster information flow and improved communication [14] between employees.

\subsubsection{Process Management Quality}

Process management, quality mentioned as an effective primary element of integrated quality efforts. Process refers to all resources used in production. TQM beliefs that the product quality starts from improving process quality direct or indirect. Building quality process in production to reduce the variation of process is the main objective of process management. By applying this the waste and rework costs of resources will be decreased while quality of output will be increased. The telecommunication company established a solid track of record by its strong management team. It makes a lot of smart systems to improve the quality management process. For example, it implements a private cloud solution to support its business service management. By applying this system, it allow the end users to access the cloud self-service portal and request services, the new service provisioning takes a 35 minute instead of weeks, it offers a high availability of staff for projects, it used enterprise change management to control infrastructure resource. The service fulfillment provisioning has a fully unattended instead of several teams. In addition, the cloud services, catalog of the system applies the quality and standard for all services. It gives a strong and efficient, utilizing reporting in the cloud.

\section{CORRELATION COEFFICIENT CALCULATIONS}

Data analyzed to calculate the correlation in two stages by using Microsoft Office Excel to analyze the data. After collecting the results of the survey, data inserted in Microsoft Excel, then start analyzing the data as first stage and checked it by applying Cronbach's Alpha to gauge its reliability. In second stage is applying the correlation analysis to assess the strength of the relationship between factors.

\subsection{Reliability Analysis}

Before testing collected data, preliminary analysis applied first to check for any violations in it. This study was applied scale of Cronbach's coefficient alpha value which is the most widely used statistics to determine the reliability of the measurement. The result of Cronbach's alpha for all factors is above 0.68 which is acceptable range and means the data reliable for measuring parameters.

See table below. The variables in the table are as following: Leadership (L), Customer Focus (CF), Strategic Planning (SP), Employee Relations (ER), Supplier Quality
Management (SQM), Process Management Quality (PMQ) and, Operational Performance (OP)

Table2: Reliability test result by using Cronbach's Alpha

\begin{tabular}{|c|c|c|}
\hline Variable & No. of items & $\begin{array}{c}\text { Alpha Reliability } \\
\text { Coefficient }\end{array}$ \\
\hline L & 3 & 0.6812 \\
\hline CF & 3 & 0.9969 \\
\hline SP & 3 & 0.9956 \\
\hline ER & 3 & 0.9973 \\
\hline SQM & 3 & 0.9987 \\
\hline PMQ & 3 & 0.9957 \\
\hline OP & 18 & 0.9801 \\
\hline
\end{tabular}

\subsection{Correlation Analysis}

Correlation provides answers to this study in looking the relations between TQM six practices and operational performance of data in a research. It also tells the direction of the relation between each factors and company performance and the magnitude of it.

The correlation coefficient value of performance and six TQM practice variables results in the table below.

Table3: correlation result between all varaibles

\begin{tabular}{|c|c|c|c|c|c|c|c|}
\hline & L & CF & SP & ER & SQM & PMQ & OP \\
\hline L & 1 & & & & & & \\
\hline CF & 0.638 & 1 & & & & & \\
\hline SP & -0.539 & 0.306 & 1 & & & & \\
\hline ER & 0.391 & 0.959 & 0.564 & 1 & & & \\
\hline SQM & -0.711 & -0.995 & -0.209 & -0.925 & 1 & & \\
\hline PMQ & 1.000 & 0.649 & -0.526 & 0.405 & -0.722 & 1 & \\
\hline OP & 0.312 & 0.931 & 0.203 & 0.996 & -0.891 & 0.327 & 1 \\
\hline
\end{tabular}

To evaluate the results if the value is positive that means the variables are correlated positively to each other which means if a variable increased the other one will be increased. On other side, if the value is negative that means the variables are negatively correlated to each other which means if a variable increased the other will be decreased. Also, if the value is greater than 0.5 that means it is strongly correlated to each other, but if it is less than 0.5 and more than 0 that means it is weakly correlated.

From the result the correlation between performance the leadership, strategic planning and, process management quality are positively correlated to the organization operational performance. In the same time the company operational performance was strongly correlated to the customer focus and, employee relations. There is a negative correlated between supplier quality management in the company and performance. 
Table4: correlation result between performance and TQM practice

\begin{tabular}{|c|c|c|}
\hline Variables & $\begin{array}{c}\text { Correlation } \\
\text { Coefficient }\end{array}$ & $\begin{array}{c}\text { Relationship } \\
\text { with Operational } \\
\text { Performance }\end{array}$ \\
\hline L & 0.312 & Week \\
\hline CF & 0.931 & Strong \\
\hline SP & 0.203 & Week \\
\hline ER & 0.996 & Strong \\
\hline SQM & -0.890 & Negative \\
\hline PMQ & 0.327 & Week \\
\hline OP & 1.000 & - \\
\hline
\end{tabular}

\section{CONCLUSION}

This research study the effect of using Total Quality Management practices on the operational performance of an organization through production performance improvement, employee morality and customer satisfaction. The relation was tested in a Saudi telecommunication company. In addition, according to the result of the analyzed data, there were a positive correlation between leadership, strategic planning, and quality management process and the organization performance. Moreover, it was strongly correlated with customer focus and, employee relations, but negatively correlated with supplier quality management. The results that have been accessed are consistent with previous studies in the literature review that there is a positive relation between the operational performance of organization and the Total Quality Management practices. In future work, toward study the effect of TQM practices in the financial performance of organization and the relation between them.

\section{ACKNOWLEDGEMENT}

The authors also, acknowledge with thanks Department of Information Systems-Faculty of Computing and Information Technology and Science and Technology Unit, King Abdulaziz University for extending all support and facilities in completing this paper.

\section{REFERENCES}

[1] Ahire, S., Golhar, D., \& Waller, M. (1996). Development and Validation of TQM Implementation Constructs. Decision Sciences, 27(1), 23-56. http://dx.doi.org/10.1111/j.1540-5915.1996.tb00842.x

[2] Anderson, J.C., Rungtusanatham, M., \& Schroeder, R.G. (1994). A Theory of Quality Management Underlying the Deming Management Method. Academy Of Management Review, 19(3), 472-509.

[3] Anderson, J.C., Rungtusanatham, M., Schroeder, R.G., \& Devaraj, S. (1995). A Path Analytic Model of a Theory of Quality Management Underlying the Deming Management Method: Preliminary Empirical Findings. Decisions Sciences, 26(5), 637-658. http://dx.doi.org/10.1111/j.1540-5915.1995.tb01444.x

[4] Bilich, F. \& Neto, A. A. (1997). Strategic total quality management. InTOTAL QUALITY MANAGEMENT,2. Retrieved from University of Kent, Department of Economics Web site: http://www.tandfonline.com/doi/pdf/10.1080/095441297 9767

[5] Chin, S. O., Fang, C. L. \& Yu, C. H., The Effects of Total Quality Management on Business Performance: Evidence from Taiwan Information-Related Industries. Retrieved from National Chung Cheng University, Department of Accounting and Information Technology Web site: https://aaahq.org/mas/MASPAPERS2007/research_foru $\mathrm{m} / \mathrm{Ou}, \% 20 \mathrm{Liu}, \% 20 \mathrm{Hung} \% 20$ and\%20Yen.pdf

[6] Gunasekaran, A. (1999). Enablers of total quality management implementation in manufacturing: a case study. Total Quality Management, 10(7), 987-996.

[7] ISO (2012). Quality Management Principles.

[8] John F. Dix and H. Lee (2002). INTRODUCTION TO STRATEGIC PLANNING. The Process Of Strategic Planning, Article 1.

[9] Jrgensen, K. B. \& Nielsen, A. F. (2013). The effects of TQM Critical Success Factors on Organizational Performance. Retrieved November 1, 2014 from MSc. Finance \& International Business Aarhus University, Business and Social Sciences Web site: http://pure.au.dk/portal/files/55321016/The_effects_of_T QM_Critical_Success_Factors_on_Organizational_Perfo rmance.pdf

[10] Malik, S. A, Iqbal, M. Z. \& Yong, J. (2010). TQM Practices \& Organizational Performance: Evidence From Pakistani SMEs. In International Journal of Engineering \& Technology,10(4). Retrieved from COMSAT Institute of Information Technology, Department of Management Sciences Web site: http://www.ijens.org/1065042727\%20ijet-ijens.pdf

[11] Sadikoglu, E. \& Olcay, H. (2013). The Effects of Total Quality Management Practices on Performance and the Reasons of and the Barriers to TQM Practices in Turkey. In Advances in Decision Sciences,2014. Retrieved November 1, 2014 from Gebze Institute of Technology, School of Business Administration Web site: http://www.hindawi.com/journals/ads/2014/537605/\#B3 9

[12] Singh, Kanwarpreet, and I.P.S. Ahuja. "Transfusion of Total Quality Management and Total Productive Maintenance: a literature review", International Journal of Technology Policy and Management, 2012

[13] Wasage, Cha. "Measuring the Effectiveness of Six Sigma Implementation in Fortune 500 Companies: An Empirical Study", Proquest, 2014

[14] K. B., \& Nielsen, A. F. (2013). The effects of TQM Critical Success Factors on Organizational Performance. Aarhus University. Retrieved 8 21, 2014, from http://pure.au.dk/portal/files/55321016/The_effects_of_T QM_Critical_Success_Facto

[15] Xia, J. (2009). Factors Influencing Chinese Suppliers' Quality Performance: A Supplier Selection Model For (Smes) To Ensure Their Chinese Supplers' Ability To Provide Quality Products. Terre Haute, Indiana. Retrieved from http://www2.bgsu.edu/colleges/technology/faculty/sinn/ Xia\%20Dissertation.pdf 